culture of communication are presented.

The main attention in the article is paid to the diagnostics of the communicative competence of the heads of vocational and technical education schools. It was determined that the process of improvement of communicative competence is connected with the development of personality. The current head of vocational school in his field should own not only knowledge, skills and abilities, but also well-developed creative, communicative and other abilities. The development of culture of communication of the heads of vocational schools should encourage leaders to obtain psychological knowledge, a desire for self-improvement, and an awareness of the necessity to develop their own culture of communication.

\title{
References
}

1. Bekh, I.D., 2008. Vykhovannia osobystosti: pidr. M.K. Kabardova, red. 4-e yzd., pererob. i dop. M.; Kyiv: Lybid.

2. Zuienko, N.O., 2009. Analiz rozvytku pohliadiv pedahohiv na komunikatyvnu kulturu osobystosti ta yoho psykholoho-pedahohichni naslidky. Problemy osvity. Nauk.-metod. zb., 59, s.78-79.

Nalchyk.

6. Mudryk, A.V., 1991.Sotsializatsiia $i$ «smutni chasy»: zbirnyk. M.: Znannia. (Nove u zhytti, nautsi, tekhnitsi; Seriia «Pedahohika i psykholohiia»).

3. Kryzhko, V.V., 2005. Teoriia ta praktyka menedzhmentu v osviti: navch. posibnyk. Vyd. 2-he dopr. K.: Osvita Ukrainy.

4. Kunitsyna, V.N., Kazarinova, N.V. ta Poholsha, V.M. 2001. Mizhosobystisne spilkuvannia. SPb.: Piter.

7. Dzeverin D.H., red., 1972. Pedahohichni idei H.S.

Skovorody. K.: Znannia.

8. Nychkalo, N.H., red., Honcharenko, S.U., uklad. ta in., 2000. Profesiina osvita: slovnyk. K.: Vyshcha shkola.

9. Rudenskyi, E.V., 1997. Sotsialna psykholohiia. Kurs lektsii. M.; Novosybirsk: NHAEiU, Sybirska 5. Leontiev, A.A., 2009. Pedahohichne spilkuvannia. uhoda.

УДК 17.023.36-027.561:37:159.9

https://doi.org/10.32835/2223-5752.2018.16.68-73.

\section{ПРОБЛЕМА ФОРМУВАННЯ ПРОФЕСІЙНО-ЕТИЧНОЇ КУЛЬТУРИ У ПСИХОЛОГО-ПЕДАГОГІЧНІЙ ЛІТЕРАТУРІ}

\section{Поліна Прохорчук,}

аспірант, молодший науковий співробітник

лабораторії науково-методичного супроводу в колежах $і$ технікумах

Інституту професійно-технічної освіти НАПН Украӥни

ORCID:0000-0003-2987-5962

e-mail:pella039@gmail.com

\section{КЛЮЧОВІ СЛОВА:}

педагогічні умови, професійно-етична культура, професійна кар'єра, саморозвиток, мотивація

\section{Реферат}

Володіння нормами загальної та професійної культури представлені в статті як важливі якості сучасного фахівця, необхідні для успішного розвитку його особистісної та професійної кар'єри. Обгрунтовано необхідність розвитку цих якостей у процесі професійної підготовки майбутніх графічних дизайнерів, як фахівців, професійна діяльність яких пов'язана 3 образотворчою діяльністю, покликаних створювати візуальні художні образи та оперувати ними. Здійснено аналіз сутності понять «професійна культура» та «педагогічні умови». Зазначено, що в сучасній науково-педагогічній літературі існують різні визначення названих понять. Показано різні погляди сучасних дослідників на обㅍунування сутності поняття «педагогічні умови формування професійно-етичної культури». 3'ясовано, що цей педагогічний феномен пояснюється здебільшого як: сукупність дій, спрямованих на поетапне моделювання й ефективне функціонування процесу становлення й розвитку належного рівня професійно-етичної культури; процес становлення особистості в результаті об'єктивного впливу спадковості, середовища, виховання, самовиховання й педагогічного управління індивідуальним становленням людської особистості. У результаті наукового аналізу психолого-педагогічної літератури виявлено й охарактеризовано основні педагогічні умови, що забезпечують процес формування професійної, етичної, моральної та професійно-етичної культури. Узагальнення поглядів учених дало змогу зробити висновок про те, що найбільш оптимальними для організації професійної підготовки майбутніх графічних дизайнерів можуть бути: вдосконалення знань про механізми творчого саморозвитку, використання інноваційних технологій для формування професійних умінь і навичок, формування позитивної мотивації до професійного успіху. 


\section{Постановка}

ознаменоване богізованоі, культури, миттєвої передачі інформації, розширення соціокультурного середовища. В умовах гуманізації та демократизації освіти різних рівнів і профілів посилюється важливість дотримання етичних норм, моралі та загальної культури в усіх сферах соціальної комунікації. При цьому, набуває актуальності формування професійної, моральної та етичної культури у майбутніх фахівців.

Набуття професійно-етичної культури, засвоєння норм загальної та професійної культури, вивчення етичного кодексу, забезпечують можливість ефективної взаємодії в соціумі, успішного особистісного та професійного розвитку. На нашу думку, це важливо враховувати під час підготовки фахівців, професійна діяльність яких пов'язана 3 образотворчою діяльністю - спеціалістів типу «людина-художній образ», які створюють візуальні образи та оперують ними, наприклад, графічних дизайнерів. В ході нашого дослідження виникла потреба у визначенні педагогічних умов формування професійноетичної культури майбутніх графічних дизайнерів.

Аналіз останніх досліджень. Педагогічні умови формування i розвитку професійної компетентності розглядали такі вітчизняні i зарубіжні вчені: Р.Гуревич, Н.Кузьміна, Ю.Кулюткін, О.Пєхота, Л.Петренко, Ю.Подповєтна, І.Соколова, В.Чобітько, Л.Шевчук та ін.; педагогічні умови розвитку педагогічної і професійної культури викладачів досліджували: І.Ісаєв,Т.Ісаєва, О.Карпова, Л.Лялікова, Н.Ничкало, Н.Павелко, О.Панова та ін.; педагогічні умови оптимізації процесу професійно-етичної підготовки фахівців різних професій представлені у працях М. Лєвіної, О.Пономаренко, 3. Макара, М. Михнюк, М. Пічкур, С. Щабельник, Т. Семигінівської. Однак з'ясовано, що дослідженню педагогічних умов розвитку професійно-етичної культури майбутніх графічних дизайнерів приділялося недостатньо уваги.

Метою статті $€$ аналіз психологопедагогічноїлітературизпроблемидослідження та узагальнення поглядів сучасних учених щодо визначення сутності педагогічних умов формування професійно-етичної культури майбутніх графічних дизайнерів.
Виклад основного матеріалу. В сучасній науково-педагогічній літературі існує кілька визначень поняття «педагогічні умови». В основі сутності даного феномену - філософське тлумачення поняття «умови», які розуміються, як обставини або середовище, від яких залежить певна річ та в яких вона функціонує (Андрущенко И.В. и др., 2006, с.707). Довідкова література пропонує також і інші визначення поняття «умови»: (Аграрова, 2010, с.588): обставина, у котрій щось відбувається; обставина, від якої щось залежить; правила, що впорядковують певну сферу життєдіяльності.

Термін «педагогічні умови» також має багато визначень, наведемо основні 3 них: комплекс заходів, зміст, методи та організаційні форми навчання і виховання особистості; комплекс об'єктивних можливостей педагогічного процесу; сукупність об'єктивних можливостей змісту навчання, методів, організаційних засобів його здійснення, коли забезпечується успішне вирішення поставленого педагогічного завдання (Высоцкий С.В., 1999, с.91); компонент педагогічної системи, сукупність внутрішніх і зовнішніх елементів, котрі забезпечують іiі ефективне існування, подальший розвиток (Левина М.А., 2012, с.69). У навчальному курсі для творчого саморозвитку В.І. Андрєєв (2000, c. 68) розглядає педагогічні умови як результат цілеспрямованого відбору, моделювання та застосування елементів змісту, методів, а також організаційних форм навчання і виховання для досягнення освітніх задач.

У дослідженні ми виходимо 3 того, що педагогічні умови формування професійноетичної культури - це сукупність дій, спрямованих на поетапне моделювання й ефективне функціонування процесу становлення й розвитку належного рівня такої культури. Відповідно до «Нового тлумачного словника української мови» (Яременко та Сліпушко, 2007, с. 666) поняття «формувати» означає «надавати чому-небудь певну форму, вигляду тощо; виробляти певні якості, риси характеру та ін.». У педагогіці формуванням називають процес становлення особистості в результаті об'єктивного впливу спадковості, середовища, цілеспрямованого виховання й власної активності (самовиховання), педагогічне управління індивідуальним становленням людської особистості.

Науковці по-різному підходять до визначення педагогічних умов форування 
професійної культури. Наприклад, М. I. Михнюк (2016, с. 3-11) називає педагогічні умови, які сприятимуть розвитку професійної культури викладачів спеціальних дисциплін будівельного профілю: формування позитивної мотивації викладачів спеціальних дисциплін до професійно-педагогічного розвитку; запровадження інноваційного досвіду роботи викладачів закладів професійної освіти; застосування суб'єкт-суб'єктної взаємодії розвитку професійної культури викладачів спеціальних дисциплін; стажування викладачів спеціальних дисциплін.

М. Лєвіна (2012, с. 27) характеризує умови, що сприяють розвитку професійно-етичної культури студента:

- організація виховного середовища, наближеного до майбутньої професійної діяльності керівника;

- стимулювання мотивації майбутніх менеджерів шляхом включення в інтерактивні форми організації навчально-виховного процесу (використання інтерактивних методів в організації навчальних занять; залучення магістрантів до вирішення управлінськопедагогічних ситуацій, участі в тренінгах i майстер-класах; створення професійноетичних автопортретів, етичного кодексу менеджера освіти);

- організаційно-методичне забезпечення навчально-виховного процесу (збагачення управлінських дисциплін змістом професійноетичного характеру; впровадження курсу «Етичні основи професійної діяльності менеджера освіти»;

- включення етико-діяльнісного компонента в програму науково-педагогічної управлінської практики).

Обидва дослідники особливо акцентують увагу на необхідності стимулювання мотивації майбутніх фахівців.

У свою чергу, М.Пічкур (2000, с. 87-98) стверджує, що для успішного формування професійної культури необхідними $€$ такі педагогічні умови: створення емоційного резонансу на основі діалогового спілкування; активізація самостійної творчо-пошукової діяльності студентів на основі міжособистісної взаємодії (викладач-студент); стимулювання творчого самовираження студентів через композиційну діяльність.

Інакший погляд на формування професійної культури має С. Щабельник (2014, с. 9). Автор вважає, що серед педагогічних умов, які сприятимуть формуванню професійної культури, мають бути: розвиток потребовомотиваційної сфери особистості студента; організація освітнього процесу на основі продуктивної творчої діяльності, спільної проектної діяльності студентів і викладачів; розробка навчально-методичного забезпечення; педагогічний контроль i корекція процесу формування професійної культури; комплексне діагностування й оцінка рівня сформованості професійної культури. О. Пономаренко (2001, с.104-107) до переліку психологопедагогічних умов ефективного формування професійно-етичної культури соціального педагога відносить: ознайомлення студентів 3 професійними знаннями, етичними нормами та гуманістичними цінностями; наявність широкого спектру практичних форм роботи, спрямованих на розвиток умінь i навичок професійної та міжособистісної взаємодії; об'єднання всіх компонентів процесу формування професійно-етичної культури в єдину цілеспрямовану систему виховання. 3. Макар (2015, с.70-82) виділяе наступні педагогічні умови в ході свого педагогічного дослідження: формування професійних вмінь молодших спеціалістів-дизайнерів у процесі фахової підготовки: формування позитивної мотивації до вдосконалення професійно-етичної діяльності і саморозвитку; застосування методів і прийомів, спрямованих на розвиток художньо-образного мислення, творчої уяви i фантазії (мотиваційнопізнавальний етап); забезпечення мотивації до творчого саморозвитку завдяки участі в конкурсах і виставках (рефлексивно-творчій етап). Узагальнення визначення вітчизняними дослідниками педагогічних умов форування професійної культури майбутніх фахівців представлено в табл. 1. 
Таблиця 1

Педагогічні умови формування професійної, етичної та професійно-етичної культури у психолого-педагогічній літературі

\begin{tabular}{|c|c|}
\hline Автор & Педагогічні умови \\
\hline М. Михнюк & $\begin{array}{l}\text { - формування позитивної мотивації до вдосконалення професійної } \\
\text { діяльності і саморозвитку; } \\
\text { - запровадження в н навчально-виховний процес закладів професійної } \\
\text { освіти передового досвіду роботи; } \\
\text { - застосування суб’єкт-суб'єктної взаємодії цього розвитку, яка передбачає } \\
\text { методичну систему наставництво - тьюторство - коучинг; } \\
\text { - стажування. }\end{array}$ \\
\hline М. Лєвіна & $\begin{array}{l}\text { - організація виховного середовища, наближеного до майбутньої } \\
\text { професійної діяльності; } \\
\text { - стимулювання мотивації майбутніх фахівців, шляхом включення в } \\
\text { інтерактивні форми організації навчально-виховного процесу; } \\
\text { - організаційно-методичне забезпечення навчально-виховного процесу. }\end{array}$ \\
\hline С. Щабельник & $\begin{array}{l}\text { - розвиток потребово-мотиваційної сфери особистості студента; } \\
\text { - організація освітнього процесу на основі продуктивної творчої діяльності, } \\
\text { спільної проектної діяльності студентів і викладачів; } \\
\text { - розробка навчально-методичного забезпечення; } \\
\text { - педагогічний контроль і корекція процесу формування професійної } \\
\text { культури; } \\
\text { - комплексне діагностування й оцінка рівня сформованості професійної } \\
\text { культури. }\end{array}$ \\
\hline М. Пічкур & $\begin{array}{l}\text { - створення емоційного резонансу на основі діалогового спілкування; } \\
\text { - активізація самостійної творчо-пошукової діяльності студентів на основі } \\
\text { міжособистісної взаємодії (викладач-студент); } \\
\text { - стимулювання творчого самовираження студентів через композиційну } \\
\text { діяльність. }\end{array}$ \\
\hline Т. Семигінівська & $\begin{array}{l}\text { - розгляд завдань формування професійної етики як однієї з пріоритетних } \\
\text { цілей підготовки студентів; } \\
\text { - здійснення професійної підготовки студентів з урахуванням особистісно- } \\
\text { зорієнтованого і діяльнісного підходів; } \\
\text { - організація навчально-виховного процесу на основі врахування наявного } \\
\text { рівня сформованості професійної етики й особистісних характеристик } \\
\text { студентів; } \\
\text { - моделювання за допомогою педагогічної технології контекстного } \\
\text { навчання з урахуванням новітніх технологій та IT. }\end{array}$ \\
\hline О. Пономаренко & $\begin{array}{l}\text { - ознайомлення студентів з професійними знаннями, етичними нормами та } \\
\text { гуманістичними цінностями; } \\
\text { - наявність широкого спектру практичних форм роботи, спрямованих на } \\
\text { розвиток умінь і навичок професійної та міжособистісної взаємодії; } \\
\text { - об’єднання всіх компонентів процесу формування професійно-етичної } \\
\text { культури в єдину цілеспрямовану систему виховання. }\end{array}$ \\
\hline 3. Макар & $\begin{array}{l}\text { - формування позитивної мотивації до вдосконалення професійно-етичної } \\
\text { діяльності і саморозвитку; } \\
\text { - застосування методів і прийомів, спрямованих на розвиток художньо- } \\
\text { образного мислення, творчої уяви й фантазії (мотиваційно-пізнавальний } \\
\text { етап); } \\
\text { - забезпечення мотивації до творчого саморозвитку завдяки участі в } \\
\text { конкурсах і виставках (рефлексивно-творчий етап). }\end{array}$ \\
\hline
\end{tabular}


Висновок. Порівняння охарактеризованих у статті підходів до визначення поняття «педагогічні умови» дає змогу стверджувати, що більшість дослідників наполягають на важливості дотримання у формуванні професійно-етичної культури фахівця будьякої галузі низки педагогічних умов, а саме: формування позитивної мотивації до вдосконалення професійно-етичної діяльності і саморозвитку; застосування методів і прийомів, спрямованих на розвиток художньо-образного мислення; забезпечення мотивації до творчого саморозвитку; використання інноваційних технологій для формування професійних умінь. Доведено, що в процесі підготовки майбутніх графічних дизайнерів потрібно створити умови для засвоєння норм загальної і професійної культури та вивчення етичного кодексу певної професії. Це сприятиме ефективній взаємодії майбутніх фахівців у соціумі та їх успішному особистісному i професійному розвитку. Перспективним залишається визначення особливостей формування професійно-етичної культури майбутніх графчних дизайнерів у коледжах.

\section{Література}

1. Аграрова, Е. А., 2010. Акмеолгчческие детерминанть развития исследователей компетентности судьи. Кандидат наук. Росс. акад. гос. службы при Президенте Росс. Федерации.

2. Андреев, В.И., 2000. Педагогика: учебный курс для творческого саморазвития. - 2-е изд. Казань: Центр инновационных технологий.

3. Высоцкий, С.В., 1999. Структура психологопедагогических условий формирования поисковотворческой направленности личности в процессе обучения. Науковий вісник Південноукраінського державного педагогічного університету ім. К. Д. Уиинського, 8-9, с.90-94.

4. Ипполитова, Н. В., 2000. Теория и практика подготовки будущиих учителей к патриотическому воспитанию учашиихся. Доктор наук. Челябинский гос. ун-Т.

5. Левина, М.А., 2012. Культурообразующиче основы профессионально-этической подготовки студентовмедииинского университета. Кандидат наук. Рязанский государственный медицинский университет имени академика И.П. Павлова.

6. Макар, 3. Ю., 2015. Формування професійних умінь молодших спеціалістів-дизайнерів у процесі фахової підготовки. Кандидат наук. Вінниця, 2015.

7. Михнюк, М. I., 2016. Теоретичні і методичні основи розвитку професійної культури викладачів спеціальних дисииплін будівельного профілю. 8. Доктор наук. Інститут професійно-технічної освіти НАПН України.

9. Пічкур, М. О., 2000. Формування професійної культури майбутнього вчителя образотворчого мистеитва (на матеріалі композииіi). Кандидат наук. Ін-т педагогіки і психології професійної освіти АПН України.

10. Пономаренко, О. В., 2001. Формування професійно-етичної культури соиіального педагога. Кандидат наук. Запорізький державний університет.

11. Андрущенко И.В., Вусатюк О.А., Линецкий С.В. та Шуба А.В. автор-сост., 2006. Философский словарь. К.: А.С.К.

12. Щабельник, С. О., 2014. Формування професійної культури майбутніх дизайнерів y прочесі вивченння педагогічних дисииплін. Кандидат наук. Харків. Українська інженернопедагогічна академія.

13. Яковлева, Н. М., 1977. Теория и практика подготовки будушего учителя $\kappa$ решению воспитательных задач. Доктор наук. Челябинск.

14. Яременко, В. та Сліпушко, О., 2007. Новий тлумачний словник украӥнської мови : у 3 т. Т. 3. К. : Аконіт.

\section{KEY WORDS:}

pedagogical conditions, professional and ethical culture, professional career, self-development, motivation

\section{Abstract}

The problem of forming the professional and ethical culture in psychological and pedagogical literature

Polina Prokhorchuk,

PhD Student, Junior Researcher of the Laboratory of Scientific and Methodological Support in Colleges and Technical Schools of the Institute of Vocational Education and Training of the National Academy of Educational Sciences of Ukraine 


\begin{abstract}
Mastering the norms of general and professional culture are presented in the article as important qualities of a modern specialist, necessary for the successful development of his personal and professional career. The necessity to develop these qualities in the process of future graphic designers' professional training as specialists with professional activity connected with graphic art, aimed to create and operate visual art images, is grounded. The content analysis of the concepts of "professional culture" and "pedagogical conditions" is made. It is mentioned that various definitions of the mentioned concepts exist in the modern scientific and pedagogical literature. The modern researchers' different views on defining the concept of "pedagogical conditions of forming the professional and ethical culture" essence are shown. It was found that this pedagogical phenomenon is explained mainly as: a set of actions aimed at stage-bystage modelling and effective functioning of the process forming and developing the sufficient level of professional and ethical culture; the process of personality's formation as a result of the objective influence of heredity, environment, education (upbringing), self-education and pedagogical management of human person's individual formation. By analysing the psychological and pedagogical literature the main pedagogical conditions are characterised; they ensure the process of forming the professional, ethical, moral, and professional and ethical culture. Summarizing the scientists' views made it possible to conclude that the most suitable for organizing the future graphic designers' professional training can be: improving the knowledge about the mechanisms of creative self-development; using the innovational technologies for professional skills forming; forming the positive motivation for professional success.
\end{abstract}

\title{
References
}

1. Agrarova, E. A., 2010. Akmeolgicheskiye determinanty razvitiya issledovateley kompetentnosti sudi. Kandidat nauk. Ross. akad. gos. sluzhby pri Prezidente Ross. Federatsii.

2. Andreyev, V.I., 2000. Pedagogika: uchebnyy kurs dlya tvorcheskogo samorazvitiya. - 2-e izd. Kazan: Tsentr innovatsionnykh tekhnologiy.

3. Vysotskiy, S.V., 1999. Struktura psikhologopedagogicheskikh usloviy formirovaniya poiskovotvorcheskoy napravlennosti lichnosti v protsesse obucheniya. Naukoviy visnik Pivdennoukrainskogo derzhavnogo pedagogichnogo universitetu im. K. D. Ushinskogo. 8-9. s.90-94.

4. Ippolitova, N. V., 2000. Teoriya i praktika podgotovkibudushchikhuchiteley kpatrioticheskomu vospitaniyu uchashchikhsya. Doktor nauk. Chelyabinskiy gos. un-t.

5. Levina, M.A., 2012. Kulturoobrazuyushchiye osnovy professionalno-eticheskoy podgotovki studentov meditsinskogo universiteta. Kandidat nauk. Ryazanskiy gosudarstvennyy meditsinskiy universitet imeni akademika I.P. Pavlova.

6. Makar, Z. Yu., 2015. Formuvannia profesiinykh umin molodshykh spetsialistivdyzaineriv u protsesi fakhovoi pidhotovky. Kandydat nauk. Vinnytsia, 2015.

7. Mykhniuk, M. I., 2016. Teoretychni $i$ metodychni osnovy rozvytku profesiinoi kultury vykladachiv spetsialnykh dystsyplin budivelnoho profiliu. Doktor nauk. Instytut profesiino-tekhnichnoi osvity NAPN Ukrainy.

8. Pichkur, M. O., 2000. Formuvannia profesiinoi kultury maibutnoho vchytelia obrazotvorchoho mystetstva (na materiali kompozytsii). Kandydat nauk. In-t pedahohiky i psykholohii profesiinoi osvity APN Ukrainy.

9. Ponomarenko, O. V., 2001. Formuvannia profesiino-etychnoi kultury sotsialnoho pedahoha. Kandydat nauk. Zaporizkyi derzhavnyi universytet.

10. Andrushchenko Y.V., Vusatiuk O.A., Lynetskyi S.V. ta Shuba A.V. avtor-sost., 2006. Fylosofskyi slovar. K.: A.S.K.

11. Shchabelnyk, S. O., 2014. Formuvannia profesiinoi kultury maibutnikh dyzaineriv u protsesi vyvchennnia pedahohichnykh dystsyplin. Kandydat nauk. Kharkiv. Ukrainska inzhenerno-pedahohichna akademiia.

12. Yakovleva, N. M., 1977. Teoriya i praktika podgotovki buduschego uchitelya $k$ resheniyu vospitatelnyih zadach. Doktor nauk. Chelyabinsk..

13. Iaremenko, V. ta Slipushko, O., 2007. Novyi tlumachnyi slovnyk ukrainskoi movy : u 3 t. T. 3. K. : Akonit. 